\title{
Impact of One Year of Pandemic on Spanish Intensive Care Units
}

Pablo Vidal-Cortés ( $\square$ pablo.vidal.cortes@sergas.es )

Hospital Universitario de Ourense

María Cruz Martín

Hospital Universitario de Torrejón

Emili Díaz

Corporació Sanitària Parc Taulí

María Bodí

Hospital Universitari Joan XXIII de Tarragona

José Carlos Igeño

Hospital San Juan de Dios, Spain

José Garnacho-Montero

Hospital Universitario Virgen Macarena

\section{Research Article}

Keywords: COVID-19, SARS-CoV-2, pandemic, ICU, Spain

Posted Date: February 7th, 2022

DOI: https://doi.org/10.21203/rs.3.rs-1316286/v1

License: () (1) This work is licensed under a Creative Commons Attribution 4.0 International License. Read Full License 


\section{Abstract}

Background:

The COVID-19 pandemic has challenged ICUs all over the world and their capacity was often exceeded. Our aim is to measure the impact of the pandemic at different levels in Spanish ICUs.

\section{Methods:}

On-line survey, conducted in April 2021, among members of the Sociedad Española de Medicina Intensiva, Crítica y Unidades Coronarias.

\section{Results:}

We received 246 answers from 157 hospitals. $67.7 \%$ of the ICUs were expanded during the pandemic, with an overall increase in beds of $58.6 \%$. The ICU medical staff increased by $6.1 \%$ and there has been a nursing shortage in $93.7 \%$ of units. In $88 \%$ of the hospitals the collaboration of other specialists was necessary to manage the patient overload, which exceeded $200 \%$ of the pre-pandemic ICU capacity. The predominant collaboration model consisted of the intensive care medicine specialist being responsible for triage and coordinating the care of critically ill patients with COVID-19. Despite that $53.2 \%$ centres offered training for critically ill patient care, a deterioration in the quality of care was perceived. $84.2 \%$ hospitals drew up a Contingency Plan and in $77.8 \%$ of the hospitals a multidisciplinary committee was set up to agree on decision-making.

Self-evaluation of the work performed was outstanding and $91.9 \%$ felt proud of what they had achieved. $16.7 \%$, however, regretted becoming intensivist and up to $15 \%$ considered leaving their job. $61.8 \%, 79.3 \%$ and $89.4 \%$ of the participants have the feeling that the opinion about the ICU has improved for hospital management, for other specialists and for the general population (respectively).

In 75.3\% of the hospitals, at least one member of the ICU medical team has been infected with COVID-19.

\section{Conclusions:}

The Spanish ICUs assumed an unprecedented increase in the number of patients. They achieved it without hardly increasing their staff and, while intensive care medicine training was carried out for other specialists who collaborated. Despite the overload, the degree of job satisfaction was consistent with prepandemic levels.

\section{Background}

Coronavirus disease 2019 (COVID-19) has meant a challenge for global healthcare systems. By 28 October 2021 over 240 million cases and approximately 5 million deaths have been declared (1). The most severe cases, admitted to Intensive Care Units (ICU), exceeded their capacity all over the world, including Spain (2-7). A relationship was established between the difficulty in accessing an ICU bed, or ICU admission during periods of overload, and a higher risk of death $(8,9)$.

The pandemic has generated a heavy overload for ICU medical staff, both as individual (10) (professionals suffered from significant work and emotional overload, together with the scientific uncertainty of treating a previously unknown disease), as a group (each unit drew up its own organizational response to maximize available resources), and also in institutional terms: the Sociedad Española de Medicina Intensiva, Crítica y Unidades Coronarias (SEMICYUC) and its working groups drew up various documents (11-20) and organized different training activities for their dissemination.

Our objective is to find out how the Spanish ICUs adapted during the first year of the pandemic and to quantify the acquisition of new equipment and the incorporation of other health professionals; in addition, we try to explore and document the feelings of the ICU medical staff.

\section{Methods}

The SEMICYUC Planning, Organization and Management Working Group and the Infectious Diseases and Sepsis Working Group developed a 113-question questionnaire that includes the following sections: 1: participant data and site baseline general data, 2: material and human resources available before and during the pandemic, 3: transversal structures created in the hospital, 4: organization and care load before and during the pandemic, 5: subjective perception of the impact of the pandemic on the role and visibility of Intensive Care Medicine, 6: impact of the pandemic on non-care activity (education, investigation...) and evaluation of activities and documents. January 2020 and February 2021 were considered as pre-pandemic and post-pandemic references, respectively. The questionnaire used can be consulted (21).

The project was approved by the Managing Board of SEMICYUC and sent to partners by e-mail. The survey period was from $15^{\text {th }}$ to $A p r i l ~ 20^{\text {th }} 2021$. Responses were voluntary and anonymous. No personal data was recorded although data on job post and unit were requested. Ethics committee approval was not considered necessary because of the type of study. The survey was voluntary, not remunerated and consent to use the data obtained was deemed implicit for taking part. For the analysis, hospitals were classified as under 200 beds, 200-500 beds and more than 500 beds.

For sections 2, 3 and 4 we analysed one response per hospital. In the event of receiving more than one answer per site, we selected the answer according to a hierarchical order (head of department, clinical chief, specialist, fellow). For the remaining sections, data is shown in aggregate form.

Percentage increases (for beds, closed boxes, negative pressure boxes, staff and guard number) were calculated using the following formula: 
Percentage increase (increase \%) variable X=(variable X February 2021-variable X January 2020)/variable X January $2020 \times 100$.

Results are shown as absolute value and percentage, and as median and p25 and p75 for qualitative and quantitative variables, respectively. Answers were analysed according to hospital size. Qualitative and quantitative variables were compared using the statistical Chi ${ }^{2}$ and Kruskall-Wallis tests, respectively. Statistically significant differences were deemed those with $p<0.05$.Results:

We received 246 answers from 157 hospitals, representing the 17 autonomous communities in which Spain is administratively distributed (Additional File 1). Of the total SEMICYUC partners who responded, 58 (23.6\%) were heads of department, 15 (6.1\%) clinical chief, 128 (50.4\%) specialists 12 (4.9\%) fellows. The median experience in the ICU was $18(9,25)$ years. A total of $108(68.4 \%)$ of the analyzed hospitals offered training in Intensive Care Medicine.

Material and human resources available during the pandemic (Table 1)

Capacity was increased in $67.7 \%$ of Spanish ICUs with an increase of $9(4,18)$ beds, which represents $58.6 \%$ compared to the number of pre-pandemic beds. The number of ICU medical staff increased by $6.1 \%$ (there was no increase in small and medium-sized hospitals, however, there was an increase of $10.6 \%$ in hospitals with more than 500 beds, $p=0.014)$.

In 119 (75.3\%) units there was at least one doctor infected with SARS-CoV-2: in 7 (46.7\%) ICU from hospitals with <200 beds, 62 (76.5\%) from hospitals with 200-500 beds and $50(80.6 \%)$ from hospitals $>500$ beds $(p=0.022)$.

On the date of completing the survey, 229 (93.1\%) of respondents had received at least one dose of the vaccine.

Transversal structures created in the hospital (Table 2)

Only $15.8 \%$ of hospitals did not design a Contingency Plan and $29.1 \%$ did not have a de-escalation plan. A COVID committee was created in $77.8 \%$ of the hospitals.

\section{Treatment organization and work overload (Table 3)}

Collaboration with other specialists was necessary in $88 \%$ of the hospitals due to the excessive number of patients, that exceeded $200 \%$ of ICU prepandemic capacity.

The negative impact of the pandemic on the assistance quality, marked on a scale from 0 to 10 , was evaluated as $8(7,10)$ but only $19(12 \%)$ units used quality indicators to measure this issue. Using the same scale, concern over higher than usual mortality was graded as $9(7,10)$. Concern over insufficient individual protection equipment (IPE) during the first wave was graded as $9(8,10)$ and concern for being infected with SARS-CoV-2 was graded as $9(8,10)$. At the time of completing the survey, these concerns were lower: lack of IPE: $3(2,6)$ and infection: $6(4,7)$.

Subjective perception of the role of Intensive Care Medicine during the pandemic (Table 4)

$61.8 \%, 79.3 \%$ and $89.4 \%$ of the participants have the feeling that the opinion about the ICU has improved for hospital manager, for other specialists and for the general population (respectively). Self-evaluation of the work performed was outstanding and $91.9 \%$ drew pride from their work. However, $16.7 \%$ experienced regretted becoming intensivist (especially in hospitals with $200-500$ beds) and up to $15 \%$ considered leaving their job.

Impact of the pandemic on non-assistance activity and evaluation of activities and documents (Table 5)

$64.2 \%, 85.8 \%$ and $76.8 \%$ of the participants consider that the pandemic has had a negative effect on fellow training, continuous medical education and on research, respectively.

\section{Discussion}

The COVID-19 pandemic put a strain on healthcare systems in general and ICUs in particular, making it necessary to expand the capacity of both hospitals and ICUs. Our main finding is to quantify this expansion in the ICUs of Spain. A total of $67.7 \%$ of ICUs were expanded and the number of ICU beds was increased by $58.6 \%$ (a median of 9 beds per ICU). However, most beds were set up in open spaces: only hospitals with more than 500 beds increased the number of isolation single beds and virtually no new negative pressure beds were created. Wahlster et al., in their global survey obtained 2700 responses from a total of 77 different countries ( $86.1 \%$ of answers from North America, Europe and Central Asia), measured the overload more subjectively than us and found that $13 \%$ of those surveyed perceived ICU beds to be fewer than needed (from $11 \%$ of those from North America to $50 \%$ of those from East Asia and Sub-Saharan Africa). Additionally, $11 \%, 21 \%$ and $23 \%$ reported shortages of mechanical ventilation equipment, non-invasive mechanical ventilation and high flow oxygen therapy devices, respectively (22). The material endowment of the Spanish ICUs was also increased, as recommended (23), but this increase in beds number and material resources is not correlated with increased availability of staff: medical staff only increased by $6.1 \%$, and almost exclusively in hospitals with more than 500 beds. Similarly, the nursing ratio per patient increased only in $30.1 \%$ of units. The difficulty in hiring new staff was generalized. The approximation of Wahlster et al. is also more subjective and the lack of ICU medical and nursing staff is reflected in $15 \%$ and $32 \%$, of their surveys, respectively (22).

Despite the minimal increase in staff, it was possible to treat $200 \%$ more patients over the ICUs baseline capacity (COVID-19 patients alone meant an increase of $175 \%$ ). It is highly likely that this treatment overload is one of the most important factors that accounts for the high mortality reported in some Spanish series $(4,5,24,25)$, as shown in the study by Bravata et al (8). In a study conducted among ICU managers in Australia, it was estimated that the 
maximum possibility of increasing the number of ICU beds and ventilators was $191 \%$ and $120 \%$ in the country, respectively; and, to assume this expansion, an increase in medical and nursing staff of $245 \%$ and $269 \%$, respectively, was considered necessary (26). As we can observe, the estimated increase in beds is comparable to the increase in patients we experienced in Spain. However, the increase in staff we attained is far from what is deemed necessary to treat such a large number of patients.

Fear for one's own health and the possibility of infecting one's family has accompanied ICU staff throughout this pandemic (22,27). This is justified by the lack of IPE components, a common phenomenon all over the world during the initial waves of the pandemic $(22,28)$. Our data is along the same lines (in fact, only $25 \%$ of ICU did not have any staff infected). However, we also observed a significant decrease in this concern with the passing of time arising from better knowledge of the disease, more availability of supplies and vaccinations.

The combination of work overload, uncertainty over the management of patients and fear has resulted in an emotional impact on ICU staff and this phenomenon appears to be generalized all over the world. Up to $52 \%$ of those surveyed by Wahlster et al. have felt emotional stress or exhaustion (22) and a survey performed among members of the European Society of Intensive Care Medicine, reports a prevalence of anxiety, depression and severe exhaustion symptoms of $46.5 \%, 30.2 \%$ and $51.0 \%$, respectively (29). From our survey we can deduce that the staff from average-sized hospitals were among those who were most impacted during the pandemic. They experienced the highest increase in beds and patients without having boosted their medical staff. This led to a $60 \%$ increase in the number of monthly guards per intensivist. It is precisely in medium-sized hospitals where more participants are detected who have regretted being intensivists. It is noteworthy that the percentage of intensivists who have considered leaving the specialty is lower than that reported in a survey conducted in Spain before the pandemic; in which $40.7 \%$ admitted having considered it (30).

In light of this situation, it is essential to have a structure that provides psychological support to ICU professionals as recommended in different documents $(23,29,31)$. More than half the hospitals offered a Psychological Support Unit and in most, multidisciplinary structures (COVID Committee) have been organised to take organisational decisions, whose work has in general been evaluated well.

From the patient management perspective, in $88 \%$ of hospitals the collaboration of specialities such as Anaesthetics, Cardiology, Paediatrics, Emergency Medicine and Pneumology, was necessary. Being aware of differences in training $(32,33)$, the predominant treatment model $(60.0 \%)$ was the one in which the ICU medical staff coordinated triage and led management of COVID-19 patients. In an attempt to improve treatment quality, training programmes were prepared for critical patient care in over half the hospitals. Despite the efforts made, there is a feeling that treatment quality has been negatively impacted both in Spanish and global ICUs. For example, changes occurred in the indication of mechanical ventilation in $16 \%$ of units and only $34 \%$ of ICUs maintained their usual policy of cardiopulmonary resuscitation (22).

Regarding non-care activity (research, education...), our results are contradictory. First, there is the general belief that the pandemic has made training and research more difficult (especially in medium-sized and large hospitals). Second, the switch from in person to online activities has been welcomed; activities carried out were evaluated positively and deemed useful as they helped update treatments received by COVID-19 patients. Furthermore, there is a predominantly critical position in regard to the "avalanche" of COVID-19 publications. 83.7\% believe that material of low scientific and methodological quality was published; and $77.2 \%$ consider that some publications without the support of scientific evidence complicated the treatment of these patients, as pointed out in some editorials during the initial phase of the pandemic $(34,35)$ and confirmed in a survey that highlighted heterogeneity in the management of these patients (36). The efforts by SEMICYUC and its working groups in drawing up documents on management of the COVID-19 patient was welcomed.

The most important strength of our survey is the information provided about how the response to the pandemic was organized in Spanish ICUs, the differences between hospitals of different sizes and the approximate measure of the effort and extra cost that this entailed for the Intensive Care Units.

Among our work's limitations we should mention that taking part was voluntary and that the response percentage over the total membership was low (approximately 10\%). Also, the answers reflect the individual perception of professionals taking part and may not represent all ICUs. However, we believe the sample does represent Spain as a whole as it includes hospitals of all sizes and every administrative region. In addition, the dynamic situation during the pandemic means that the situation reflected in the results must be considered limited to the time of the survey. No objective outcome indicators have been evaluated nor have they been linked to variables such as care overload or availability of new material; nor has the impact of the pandemic on the families of critically ill patients been assessed, what has showed to be extremely important (37).

In regard to the future, it is time to set out strategies that enable adapting medical and nursing staff and material resources to the new situation. The prevailing standards (38) and the number of places for Intensive Care Medicine fellow should be reviewed. It would also be convenient to provide our hospitals with the capacity to increase the staff (mainly through training programs or stable platforms that allow a faster incorporation of teaching material) and material resources depending on the needs $(31,39)$.

It is essential and urgent to pay attention to the psychological condition of ICU workers, primarily, for health reasons, but also to avoid reducing the number of available staff, and for this it is necessary to have psychological support units, but also to improve communication and reduce care overload by adapting number of working staff to the so-called "new normality".

\section{Conclusions}

In our study we try to quantify the work overload caused by the pandemic in Spanish ICUs. Spanish ICUs assumed an unprecedented increase in the number of admitted patients, which doubled the number of beds available before the pandemic, without increasing their staff and while training was offered to other specialists who collaborated in critically ill patient management. Despite the concern about the deterioration of the quality of care, the degree of satisfaction with the work performed is high. 


\section{List Of Abbreviations}

COVID-19. Coronavirus disease 2019

ECCO2-R: system for extracorporeal elimination of $\mathrm{CO} 2$

ECMO: extracorporeal membrane oxygenation system

EFT: extracorporeal filtration techniques

HD: haemodynamics

HFO: high flow oxygen therapy

ICU: Intensive Care Unit

IQR: interquartile range

MV: mechanical ventilation

NIMV: non-invasive mechanical ventilation

SARS-CoV-2: severe acute respiratory syndrome-coronavirus-2

SEMICYUC: Sociedad Española de Medicina Intensiva, Crítica y Unidades Coronarias

\section{Declarations}

\section{Ethics approval and consent to participate}

Not applicable

\section{Consent for publication}

Not applicable

\section{Availability of data and materials}

The datasets used and/or analysed during the current study are available from the corresponding author on reasonable request.

\section{Competing interests}

The authors declare that they have no competing interests

\section{Funding}

Not applicable

\section{Authors' contributions}

MCM, ED, MB, JCl and JGM have participated in the design of the work, in the interpretation of data and have revised the manuscript, approved the submitted version and have agreed both to be personally accountable for the author's own contributions and to ensure that questions related to the accuracy or integrity of any part of the work, even ones in which the author was not personally involved, are appropriately investigated, resolved, and the resolution documented in the literature.

PVC has participated in the conception and design of the work; in analysis, and interpretation of data and have drafted the work. He has approved the submitted version and agreed both to be personally accountable for the author's own contributions and to ensure that questions related to the accuracy or integrity of any part of the work, even ones in which the author was not personally involved, are appropriately investigated, resolved, and the resolution documented in the literature.

\section{Acknowledgements}

The authors want to publicly show their gratitude to all SEMICYUC members who responded to the survey and to SEMICYUC for their support

\section{References}

1. WHO Director-General's opening remarks at the media briefing on COVID-19 - 11 March 2020 [Internet]. [cited 2020 Apr 13]. Available from: https://www.who.int/dg/speeches/detail/who-director-general-s-opening-remarks-at-the-media-briefing-on-covid-19--11-march-2020 
2. Grasselli G, Zangrillo A, Zanella A, Antonelli M, Cabrini L, Castelli A, et al. Baseline Characteristics and Outcomes of 1591 Patients Infected With SARSCoV-2 Admitted to ICUs of the Lombardy Region, Italy. JAMA. 2020 Apr 28;323(16):1574-81.

3. Xie J, Wu W, Li S, Hu Y, Hu M, Li J, et al. Clinical characteristics and outcomes of critically ill patients with novel coronavirus infectious disease (COVID19) in China: a retrospective multicenter study. Intensive Care Med. 2020 Oct;46(10):1863-72.

4. Barrasa H, Rello J, Tejada S, Martín A, Balziskueta G, Vinuesa C, et al. SARS-CoV-2 in Spanish Intensive Care Units: Early experience with 15-day survival in Vitoria. Anaesth Crit Care Pain Med. 2020;39(5):553-61.

5. Rodríguez A, Moreno G, Gómez J, Carbonell R, Picó-Plana E, Benavent Bofill C, et al. Severe infection due to the SARS-CoV-2 coronavirus: Experience of a tertiary hospital with COVID-19 patients during the 2020 pandemic. Med Intensiva. 2020;44(9):525-33.

6. Vidal-Cortés P, Del Río-Carbajo L, Nieto-Del Olmo J, Prol-Silva E, Tizón-Varela Al, Rodríguez-Vázquez A, et al. COVID-19 and Acute Respiratory Distress Syndrome. Impact of corticosteroid treatment and predictors of poor outcome. Rev Esp Quimioter. 2021 Feb;34(1):33-43.

7. Estella Á, Garcia Garmendia JL, de la Fuente C, Machado Casas JF, Yuste ME, Amaya Villar R, et al. Predictive factors of six-week mortality in critically ill patients with SARS-CoV-2: A multicenter prospective study. Med Intensiva (Engl Ed). 2021 Mar 8;

8. Bravata DM, Perkins AJ, Myers LJ, Arling G, Zhang Y, Zillich AJ, et al. Association of Intensive Care Unit Patient Load and Demand With Mortality Rates in US Department of Veterans Affairs Hospitals During the COVID-19 Pandemic. JAMA Netw Open. 2021 Jan 4;4(1):e2034266.

9. Bauer J, Brüggmann D, Klingelhöfer D, Maier W, Schwettmann L, Weiss DJ, et al. Access to intensive care in 14 European countries: a spatial analysis of intensive care need and capacity in the light of COVID-19. Intensive Care Med. 2020 Nov;46(11):2026-34.

10. Ferrer R. [COVID-19 Pandemic: the greatest challenge in the history of critical care]. Med Intensiva (Engl Ed). 2020 Sep;44(6):323-4.

11. Rascado Sedes P, Ballesteros Sanz MA, Bodí Saera MA, Carrasco Rodríguez-Rey LF, Castellanos Ortega A, Catalán González M, et al. [Contingency plan for the intensive care services for the COVID-19 pandemic]. Med Intensiva. 2020 Sep;44(6):363-70.

12. Cinesi Gómez C, Peñuelas Rodríguez Ó, Luján Torné M, Egea Santaolalla C, Masa Jiménez JF, García Fernández J, et al. [Clinical consensus recommendations regarding non-invasive respiratory support in the adult patient with acute respiratory failure secondary to SARS-CoV-2 infection]. Med Intensiva. 2020 Oct;44(7):429-38.

13. Ballesteros Sanz MÁ, Hernández-Tejedor A, Estella Á, Jiménez Rivera JJ, González de Molina Ortiz FJ, Sandiumenge Camps A, et al. [Recommendations of the Working Groups from the Spanish Society of Intensive and Critical Care Medicine and Coronary Units (SEMICYUC) for the management of adult critically ill patients in the coronavirus disease (COVID-19)]. Med Intensiva (Engl Ed). 2020 Sep;44(6):371-88.

14. Martín Delgado MC, Avilés-Jurado FX, Álvarez Escudero J, Aldecoa Álvarez-Santuyano C, de Haro López C, Díaz de Cerio Canduela P, et al. [Consensus document of the Spanish Society of Intensive and Critical Care Medicine and Coronary Units (SEMICYUC), the Spanish Society of Otorhinolaryngology and Head and Neck Surgery (SEORL-CCC) and the Spanish Society of Anesthesiology and Resuscitation (SEDAR) on tracheotomy in patients with COVID-19 infection]. Med Intensiva (Engl Ed). 2020 Nov;44(8):493-9.

15. Rubio O, Estella A, Cabre L, Saralegui-Reta I, Martin MC, Zapata L, et al. [Ethical recommendations for a difficult decision-making in intensive care units due to the exceptional situation of crisis by the COVID-19 pandemia: A rapid review \& consensus of experts]. Med Intensiva. 2020 Oct;44(7):439-45.

16. Fraile Gutiérrez V, Ayuela Azcárate JM, Pérez-Torres D, Zapata L, Rodríguez Yakushev A, Ochagavía A. [Ultrasound in the management of the critically ill patient with SARS-CoV-2 infection (COVID-19): narrative review]. Med Intensiva. 2020 Dec;44(9):551-65.

17. Rodríguez Yago MA, Alcalde Mayayo I, Gómez López R, Parias Ángel MN, Pérez Miranda A, Canals Aracil M, et al. [Recommendations on cardiopulmonary resuscitation in patients with suspected or confirmed SARS-CoV-2 infection (COVID-19). Executive summary]. Med Intensiva. 2020 Dec;44(9):566-76.

18. Díaz E, Amézaga Menéndez R, Vidal Cortés P, Escapa MG, Suberviola B, Serrano Lázaro A, et al. [Pharmacological treatment of COVID-19: Narrative review of the Working Group in Infectious Diseases and Sepsis (GTEIS) and the Working Groups in Transfusions and Blood Products (GTTH)]. Med Intensiva. 2021 Mar;45(2):104-21.

19. Llau JV, Ferrandis R, Sierra P, Hidalgo F, Cassinello C, Gómez-Luque A, et al. SEDAR-SEMICYUC consensus on the management of haemostasis disorders in severe COVID-19 patients. Med Intensiva (Engl Ed). 2020 Sep 6;

20. Vidal-Cortés P, Santos ED, Alonso EA, Menéndez RA, Ballesteros MÁ, Bodí MA, et al. [Recommendations for the management of critically ill patients with COVID-19 in Intensive Care Units]. Med Intensiva (Engl Ed). 2021 Sep 16;

21. Cuestionario para medir el impacto de la pandemia en las UCl españolas. [cited 2022 Feb 1]. Available from: https://forms.office.com/Pages/ResponsePage.aspx?id=X63NxNehdE-

L1fEd5wVvNAYn8L75N3xMoaG2rBa8729UNk44MERGNFZMTFNFTDRBVIpGV1ZJOUxCMi4u

22. Wahlster S, Sharma M, Lewis AK, Patel PV, Hartog CS, Jannotta G, et al. The Coronavirus Disease 2019 Pandemic's Effect on Critical Care Resources and Health-Care Providers: A Global Survey. Chest. 2021 Feb;159(2):619-33.

23. Aziz S, Arabi YM, Alhazzani W, Evans L, Citerio G, Fischkoff K, et al. Managing ICU surge during the COVID-19 crisis: rapid guidelines. Intensive Care Med. 2020 Jul;46(7):1303-25.

24. Ramírez P, Gordón M, Martín-Cerezuela M, Villarreal E, Sancho E, Padrós M, et al. Acute respiratory distress syndrome due to COVID-19. Clinical and prognostic features from a medical Critical Care Unit in Valencia, Spain. Med Intensiva. 2021 Feb;45(1):27-34.

25. Ferrando C, Suarez-Sipmann F, Mellado-Artigas R, Hernández M, Gea A, Arruti E, et al. Clinical features, ventilatory management, and outcome of ARDS caused by COVID-19 are similar to other causes of ARDS. Intensive Care Med. 2020 Dec;46(12):2200-11. 
26. Litton E, Bucci T, Chavan S, Ho YY, Holley A, Howard G, et al. Surge capacity of intensive care units in case of acute increase in demand caused by COVID-19 in Australia. Med J Aust. 2020 Jun;212(10):463-7.

27. Fernández-Castillo R-J, González-Caro M-D, Fernández-García E, Porcel-Gálvez A-M, Garnacho-Montero J. Intensive care nurses' experiences during the COVID-19 pandemic: A qualitative study. Nurs Crit Care. 2021 Sep;26(5):397-406.

28. Tabah A, Ramanan M, Laupland KB, Buetti N, Cortegiani A, Mellinghoff $\mathrm{J}$, et al. Personal protective equipment and intensive care unit healthcare worker safety in the COVID-19 era (PPE-SAFE): An international survey. J Crit Care. 2020 Oct;59:70-5.

29. Azoulay E, De Waele J, Ferrer R, Staudinger T, Borkowska M, Povoa P, et al. Symptoms of burnout in intensive care unit specialists facing the COVID-19 outbreak. Ann Intensive Care. 2020 Aug 8;10(1):110.

30. Rodriguez-Ruiz E, Campelo-Izquierdo M, Veiras PB, Rodríguez MM, Estany-Gestal A, Hortas AB, et al. Moral distress among healthcare professionals working in intensive care units in Spain. Med Intensiva (Engl Ed). 2021 Jul 28;S0210-5691(21)00170-4.

31. Vranas KC, Golden SE, Mathews KS, Schutz A, Valley TS, Duggal A, et al. The Influence of the COVID-19 Pandemic on ICU Organization, Care Processes, and Frontline Clinician Experiences: A Qualitative Study. Chest. 2021 May 29;S0012-3692(21)01069-2.

32. Vidal-Cortés P, Nuvials-Casals X, Maseda-Garrido E, Sancho-Chinesta S, Suberviola-Cañas B, González-Castro R, et al. Organization of attention to infectious pathology in critical care units in Spain. Med Intensiva (Engl Ed). 2020 Sep 30;S0210-5691(20)30263-1.

33. Roshdy A, Elsayed AS, Saleh AS. Intensivists' perceptions and attitudes towards infectious diseases management in the ICU: An international survey. Med Intensiva (Engl Ed). 2021 Aug 17;S0210-5691(21)00174-1.

34. Kalil AC. Treating COVID-19-Off-Label Drug Use, Compassionate Use, and Randomized Clinical Trials During Pandemics. JAMA. 2020 May 19;323(19):1897-8.

35. Estella Á, Garnacho-Montero J. [From empiricism to scientific evidence in antiviral treatment in severe cases of coronavirus infection in times of epidemic]. Med Intensiva. 2020 Nov;44(8):509-12.

36. Azoulay E, de Waele J, Ferrer R, Staudinger T, Borkowska M, Povoa P, et al. International variation in the management of severe COVID-19 patients. Crit Care. 2020 Aug 5;24(1):486.

37. Azoulay É, Curtis JR, Kentish-Barnes N. Ten reasons for focusing on the care we provide for family members of critically ill patients with COVID-19. Intensive Care Med. 2021 Feb;47(2):230-3.

38. Ministerio de Sanidad y Política Asistencial. Unidad de cuidados intensivos. Estándares y recomendaciones. [Internet]. Available from: https://www.google.com/url?

sa=t\&rct=j\&q=\&esrc=s\&source=web\&cd=\&ved=2ahUKEwifidj117rwAhW4DmMBHeLNACOQFjAAegQIBBAD\&url=https\%3A\%2F\%2Fwww.mscbs.gob.es\%2 Forganizacion\%2Fsns\%2FplanCalidadSNS\%2Fdocs\%2FUCI.pdf\&usg=AOvVaw3NtWxmDsPBSVXPVrfPB40B

39. Sasangohar F, Jones SL, Masud FN, Vahidy FS, Kash BA. Provider Burnout and Fatigue During the COVID-19 Pandemic: Lessons Learned From a HighVolume Intensive Care Unit. Anesth Analg. 2020 Jul;131(1):106-11.

40. Rascado Sedes, P, Ballesteros Sanz MÁ, Álvarez Lerma F, Bodí Saera, MA, Carrasco Rodríguez-Rey LF, Castellanos Ortega A. Plan de desescalada para los servicios de Medicina Intensiva tras la pandemia producida por la COVID-19 [Internet]. Available from: https://semicyuc.org/wpcontent/uploads/2020/07/RESUMEN-PLAN-DESESCALADA-SEMICYUC-SEEIUC-FEPIMCTI.pdf

\section{Tables}

Table 1. Human and material resources. 


\begin{tabular}{|c|c|c|c|c|c|}
\hline & \multirow[t]{2}{*}{ Overall } & \multicolumn{3}{|l|}{ Hospital size } & \multirow[t]{2}{*}{$P$} \\
\hline & & $<200$ beds & $200-500$ beds & $>500$ beds & \\
\hline Number of hospitals & 157 & $15(9.6)$ & $80(51.0)$ & $62(39.5)$ & \\
\hline Beds per unit in January 2020 & $16(10,27)$ & $6(6,8)$ & $12(10,16)$ & $30(21.5,35)$ & $<0.001$ \\
\hline Beds per unit in February 2021 & $28(16,41)$ & $10(7,15)$ & $22(15.25,30)$ & $42(34,55)$ & $<0.001$ \\
\hline Beds increase (\%) & $58.6(21.4,108.3)$ & $60(0,133.3)$ & $72.1(30.2,117.6)$ & $43.7(20,96.9)$ & 0,151 \\
\hline Isolation beds 2020 & $11(6,18)$ & $6(2,8)$ & $10(5.3,13.8)$ & $19(7.8,30)$ & $<0.001$ \\
\hline Isolation beds 2021 & $13(8,25)$ & $6(6,8)$ & $12(8,16)$ & $27.5(12.8,37)$ & $<0.001$ \\
\hline Increase in isolation beds (\%) & $0(0,57.1)$ & $0(0,50)$ & $0(0,66.7)$ & $16.8(0,53.6)$ & 0,469 \\
\hline Pressure negative beds 2020 & $0(0,2)$ & $0(0,0)$ & $0(0,2)$ & $0(0,3)$ & 0,025 \\
\hline Pressure negative beds 2021 & $1(0,6)$ & $0(0,0)$ & $2(0,7)$ & $2(0,6)$ & 0,003 \\
\hline Increase in pressure negative beds (\%) & $0(0,20)$ & $0(0,0)$ & $0(0,87.5)$ & $0(0,0)$ & 0.230 \\
\hline Medical staff in January 2020 & $11(8,16)$ & $6(5,8)$ & $9(7,12)$ & $17(14,22)$ & \\
\hline Medical staff in February 2021 & $11(9,18)$ & $6(5,8)$ & $10(8,12)$ & $19.5(25.3,26.8)$ & \\
\hline Increase in medical staff (\%) & $6.1(0,20)$ & $0(0,0)$ & $0(0,20)$ & $10.6(0,21.8)$ & 0.014 \\
\hline Guards per physician pre-pandemic & $5(4,5)$ & $6(5,6)$ & $5(4,5)$ & $4.5(4,5)$ & 0.001 \\
\hline Guards per physician during pandemic & $7(6,8)$ & $7(6,7)$ & $7(6,8)$ & $6.3(6,7)$ & 0,006 \\
\hline Increase in guards (\%) & $40(20,75)$ & $16.7(0,40)$ & $60(25,100)$ & $40(22.5,56.3)$ & 0,002 \\
\hline Increase in nursing ratio $-n(\%)-$ & $47(30.1)$ & $3(20.0)$ & $27(33.8)$ & 17 (27.9) & 0.502 \\
\hline Difficulty in hiring nursing staff -n (\%)- & $148(93.7)$ & $14(93.3)$ & $76(93.8)$ & $58(93.5)$ & 0,882 \\
\hline Extension of the ICU performed $-n(\%)-$ & $107(67.7)$ & $11(73.3)$ & $56(69.1)$ & $40(64.5)$ & 0.742 \\
\hline Extension of the ICU scheduled $-n(\%)-$ & $72(45.6)$ & $7(46.7)$ & $35(43.2)$ & $30(48.4)$ & 0.437 \\
\hline \multicolumn{6}{|l|}{ Acquisition of material } \\
\hline HFO -n (\%)- & $150(94.9)$ & $14(93.3)$ & $77(95.1)$ & $59(95.2)$ & 0.956 \\
\hline NIMV -n (\%)- & $107(67.7)$ & $7(46.7)$ & $61(75.3)$ & 39 (62.9) & 0,100 \\
\hline MV -n (\%)- & $149(94.3)$ & $12(80.0)$ & 79 (97.5) & $58(93.5)$ & 0.047 \\
\hline ECMO -n (\%)- & $31(19.6)$ & $0(0)$ & $5(6.2)$ & $26(41.9)$ & $<0.001$ \\
\hline $\mathrm{ECCO}_{2}-\mathrm{R}-\mathrm{n}(\%)-$ & $21(13.3)$ & $1(6.7)$ & $10(12.3)$ & $10(16.1)$ & 0.292 \\
\hline Monitors -n (\%)- & $107(67.7)$ & $8(53.3)$ & $55(67.9)$ & $44(71.0)$ & 0.502 \\
\hline HD monitoring system -n (\%)- & $57(36.1)$ & $2(13.3)$ & $27(33.3)$ & $28(45.2)$ & 0.063 \\
\hline Respiratory monitoring system - $\mathrm{n}(\%)-$ & $43(27.2)$ & $1(6.7)$ & $22(27.2)$ & $20(32.3)$ & 0.111 \\
\hline Ultrasound -n (\%)- & $87(55.1)$ & $8(53.3)$ & $42(51.9)$ & 37 (59.7) & 0.432 \\
\hline EFT equipment $-n(\%)-$ & $48(30.4)$ & $7(46.7)$ & $22(27.2)$ & $19(30.6)$ & 0.516 \\
\hline
\end{tabular}

Unless expressed otherwise, results are shown as median and IQR

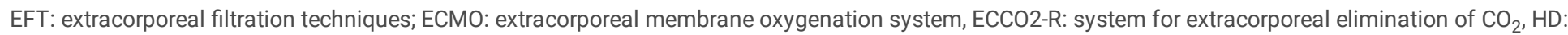
haemodynamics, HFO: high flow oxygen therapy, IQR: interquartile range, MV: mechanical ventilation, NIMV: non-invasive mechanical ventilation

*Extension of the ICU: permanent extension of the number of ICU beds

Table 2. Transversal structures created in hospital. 


\begin{tabular}{|c|c|c|c|c|c|}
\hline & \multirow[t]{2}{*}{ Overall } & \multicolumn{3}{|l|}{ Hospital size } & \multirow[t]{2}{*}{$P$} \\
\hline & & $<200$ beds & $200-500$ beds & $>500$ beds & \\
\hline Number of hospitals & 157 & $15(9.6)$ & $80(51.0)$ & $62(39.5)$ & \\
\hline COVID committee -n (\%)- & $123(77.8)$ & $9(60.0)$ & $61(75.3)$ & $53(85.5)$ & 0.177 \\
\hline Evaluation COVID committee operation (0-10) & $7(6,8)$ & $8(5.75,9.0)$ & $7(6,8)$ & $7(5,8)$ & 0.161 \\
\hline Evaluation quality of communication with superiors $(0-10)$ & $7(5,8)$ & $7(6,9)$ & $7(5,9)$ & $6(4,8)$ & 0.005 \\
\hline Psychological support unit -n (\%)- & $84(53.2)$ & $6(40.0)$ & $42(51.9)$ & $36(58.1)$ & 0.672 \\
\hline Evaluation psychological support unit tool (0-10) & $6(5,8)$ & $8(5.75,9.25)$ & $6(5,8)$ & $6(3,8)$ & 0.204 \\
\hline Contingency Plan -n (\%)- & $133(84.2)$ & $13(86.7)$ & $67(82.7)$ & $53(85.5)$ & 0.959 \\
\hline De-escalation Plan -n (\%)- & $112(70.9)$ & $11(73.3)$ & $54(66.7)$ & $47(75.8)$ & 0.072 \\
\hline
\end{tabular}

Unless expressed otherwise, results are shown as median and IQR

Table 3. Treatment organization and overload.

\begin{tabular}{|c|c|c|c|c|c|}
\hline & \multirow[t]{2}{*}{ Overall } & \multicolumn{3}{|l|}{ Hospital size } & \multirow[t]{2}{*}{$P$} \\
\hline & & $<200$ beds & $200-500$ beds & $>500$ beds & \\
\hline Maximum admitted patients at the same time & $34(21.2,48)$ & $15(9,19)$ & $29(20,38)$ & $47.5(35,70)$ & $<0.001$ \\
\hline $\begin{array}{l}\text { Maximum COVID patients admitted at the same } \\
\text { time }\end{array}$ & $28(17.8,42)$ & $11(6.8,14.3)$ & $24(16,35)$ & $40(26,60.5)$ & $<0.001$ \\
\hline Maximum peak patients/beds January 2020 & $200(150,269.8)$ & $166.7(100,262.5)$ & $\begin{array}{l}240.8(173.5 \\
291.5)\end{array}$ & $\begin{array}{l}190.5(137.4 \\
229.9)\end{array}$ & 0.007 \\
\hline Maximum peak COVID patients/beds January 2020 & $\begin{array}{l}175(116.6 \\
239.9)\end{array}$ & $\begin{array}{l}142.1(85.9 \\
212.5)\end{array}$ & $\begin{array}{l}200.0(150.0 \\
250.0)\end{array}$ & $\begin{array}{l}\text { 161.4 (100.0, } \\
208.4)\end{array}$ & 0.035 \\
\hline Treatment in open cohorts $-n(\%)-$ & $86(54.4)$ & $6(40.0)$ & $45(55.6)$ & $35(56.5)$ & 0.131 \\
\hline \multicolumn{6}{|l|}{ Collaboration from other specialities } \\
\hline Other specialities -n (\%)- & $139(88.0)$ & $11(73.3)$ & $71(87.7)$ & $57(91.9)$ & 0.138 \\
\hline Anaesthesiology -n (\%)- & $134(84.8)$ & $10(66.7)$ & $68(85.0)$ & $56(90.3)$ & 0.005 \\
\hline Cardiology -n (\%)- & $29(18.4)$ & $0(0)$ & $12(14.8)$ & $17(27.4)$ & 0.025 \\
\hline Paediatrics -n (\%)- & $39(24.7)$ & $1(6.7)$ & $14(17.3)$ & $24(38.7)$ & 0,006 \\
\hline Emergency Department -n (\%)- & $23(14.6)$ & $2(14.6)$ & $12(14.8)$ & $9(14.5)$ & 0,924 \\
\hline Pneumology -n (\%)- & $23(14.6)$ & $1(6.7)$ & $12(14.8)$ & $10(16.1)$ & 0.698 \\
\hline \multicolumn{6}{|l|}{ Mode of collaboration } \\
\hline Coordination (triage and care) by ICU -n (\%)- & $87(60.0)$ & $9(75.0)$ & $45(60.0)$ & $33(56.9)$ & 0,507 \\
\hline Triage by ICU -n (\%)- & $43(29.7)$ & $3(25)$ & $22(29.3)$ & $18(31.0)$ & 0.913 \\
\hline Independent management -n (\%)- & $15(10.3)$ & $0(0)$ & $8(10.7)$ & $7(12.1)$ & 0,454 \\
\hline \multicolumn{6}{|l|}{ Critical patient care training } \\
\hline Programme based on SPACE-19 -n (\%)- & $25(15.8)$ & $0(0)$ & $14(17.3)$ & $11(17.7)$ & 0.192 \\
\hline Local training programme $-\mathrm{n}(\%)-$ & $56(35.4)$ & $9(60.0)$ & $25(30.9)$ & $22(35.5)$ & 0.192 \\
\hline No training programme $-n(\%)-$ & $74(46.8)$ & $6(40.0)$ & $39(48.1)$ & $29(46.8)$ & 0,192 \\
\hline
\end{tabular}

Unless expressed otherwise, results are shown as median and IQR

Table 4. Personal perception of the impact of the ICUs response to the pandemic 


\begin{tabular}{|c|c|c|c|c|c|}
\hline & \multirow{2}{*}{$\begin{array}{l}\text { Total } \\
\mathrm{N}=\mathbf{2 4 6}\end{array}$} & \multicolumn{3}{|l|}{ Hospital beds } & \multirow[t]{2}{*}{$P$} \\
\hline & & $<200$ & $200-500$ & $>500$ & \\
\hline $\begin{array}{l}\text { Has the opinion of hospital manager about the ICU improved? } \\
-n(\%)-\end{array}$ & $152(61.8)$ & $13(81.3)$ & $72(68.6)$ & $67(53.6)$ & 0.040 \\
\hline $\begin{array}{l}\text { Has the opinion of other colleagues about the ICU improved? } \\
-n(\%)-\end{array}$ & $195(79.3)$ & $14(87.5)$ & $89(84.8)$ & $92(73.6)$ & 0.254 \\
\hline $\begin{array}{l}\text { Has the opinion of general population about the ICU improved? } \\
-n(\%)-\end{array}$ & $220(89.4)$ & $16(100)$ & $90(85.7)$ & $114(91.2)$ & 0.255 \\
\hline Evaluate your work during the pandemic (0-10) & $8(8,9)$ & $9(8,10)$ & $8(8,9)$ & $8(8,9)$ & 0.171 \\
\hline Evaluate your ICU's work during the pandemic $(0-10)$ & $9(8,10)$ & $8.5(8,9.75)$ & $9(8,10)$ & $9(8,10)$ & 0.627 \\
\hline Evaluate the role of Intensive Care Medicine during the pandemic (0-10) & $9(9,10)$ & $10(15.25,10)$ & $9(9,10)$ & $9(9,10)$ & 0.739 \\
\hline Have you regretted being an intensivist? -n (\%)- & $41(16.7)$ & $0(0)$ & $28(26.7)$ & $13(10.4)$ & 0.001 \\
\hline Have you considered leaving the speciality? -n (\%)- & $37(15.0)$ & $0(0)$ & $23(21.9)$ & $14(11.2)$ & 0.073 \\
\hline Have you felt proud to be an intensivist? -n (\%)- & $226(91.9)$ & $16(100)$ & $94(89.5)$ & $116(92.8)$ & 0.311 \\
\hline \multicolumn{6}{|l|}{ Relationship between ICU medical staff } \\
\hline Worse -n (\%)- & $74(30.1)$ & $0(0)$ & $28(26.7)$ & $46(36.8)$ & \multirow[t]{3}{*}{0,031} \\
\hline Better -n (\%)- & $98(39.8)$ & $8(50)$ & $44(41.9)$ & $46(36.8)$ & \\
\hline Same -n (\%)- & $74(30.1)$ & $8(50)$ & $33(31.4)$ & $33(26.4)$ & \\
\hline \multicolumn{6}{|l|}{ Relationship between ICU medical and nursing staff } \\
\hline Worse -n (\%)- & $54(22)$ & $0(0)$ & $24(22.9)$ & $30(24.0)$ & \multirow[t]{3}{*}{0,160} \\
\hline Better -n (\%)- & $98(39.8)$ & $10(62.5)$ & $38(36.2)$ & $50(40.0)$ & \\
\hline Same -n (\%)- & $94(38.2)$ & $6(37.5)$ & $43(41.0)$ & $45(36.0)$ & \\
\hline
\end{tabular}

Unless expressed otherwise, results are shown as median and IQR

Table 5. Impact of the pandemic and opinion on activities and publications 


\begin{tabular}{|c|c|c|c|c|c|}
\hline & \multirow{2}{*}{$\begin{array}{l}\text { Total } \\
\mathrm{N}=\mathbf{2 4 6}\end{array}$} & \multicolumn{2}{|c|}{ Hospital beds } & \multirow{2}{*}{$>500$} & \multirow[t]{2}{*}{$P$} \\
\hline & & $<200$ & $\begin{array}{l}200- \\
500\end{array}$ & & \\
\hline \multicolumn{6}{|l|}{ Negative impact of the pandemic } \\
\hline Fellow Training & $\begin{array}{l}158 \\
(64.2)\end{array}$ & $\begin{array}{l}1 \\
(6.3)\end{array}$ & $\begin{array}{l}65 \\
(61.9)\end{array}$ & $\begin{array}{l}92 \\
(73.6)\end{array}$ & $<0.001$ \\
\hline Continuous Medical Education & $\begin{array}{l}211 \\
(85.8)\end{array}$ & $\begin{array}{l}10 \\
(62.5)\end{array}$ & $\begin{array}{l}93 \\
(88.6)\end{array}$ & $\begin{array}{l}108 \\
(86.4)\end{array}$ & $<0.001$ \\
\hline Research in the unit & $\begin{array}{l}189 \\
(76.8)\end{array}$ & $\begin{array}{l}11 \\
(68.8)\end{array}$ & $\begin{array}{l}82 \\
(78.1)\end{array}$ & $\begin{array}{l}96 \\
(76.8)\end{array}$ & 0.001 \\
\hline \multicolumn{6}{|l|}{ Do you agree with the following statements? } \\
\hline On-line activities have been essential & $\begin{array}{l}201 \\
(81.7)\end{array}$ & $\begin{array}{l}16 \\
(100)\end{array}$ & $\begin{array}{l}79 \\
(75.2)\end{array}$ & $\begin{array}{l}106 \\
(84.8)\end{array}$ & 0.178 \\
\hline On-line activities have modified the way COVID-19 is treated & $\begin{array}{l}150 \\
(61.0)\end{array}$ & $\begin{array}{l}14 \\
(87.5)\end{array}$ & $\begin{array}{l}63 \\
(60.0)\end{array}$ & $\begin{array}{l}73 \\
(58.4)\end{array}$ & 0.029 \\
\hline On-line activities have led to more questions than answers & $\begin{array}{l}53 \\
(21.5)\end{array}$ & $\begin{array}{l}2 \\
(12.5)\end{array}$ & $\begin{array}{l}25 \\
(23.8)\end{array}$ & $\begin{array}{l}26 \\
(20.8)\end{array}$ & 0.770 \\
\hline I prefer on-line to in person activities & $\begin{array}{l}76 \\
(30.9)\end{array}$ & $\begin{array}{l}8 \\
(50.0)\end{array}$ & $\begin{array}{l}30 \\
(28.6)\end{array}$ & $\begin{array}{l}38 \\
(50.0)\end{array}$ & 0.440 \\
\hline There have been too many activities with little value & $\begin{array}{l}162 \\
(65.9)\end{array}$ & $\begin{array}{l}5 \\
(31.3)\end{array}$ & $\begin{array}{l}77 \\
(73.3)\end{array}$ & $\begin{array}{l}80 \\
(64.0)\end{array}$ & 0.036 \\
\hline There have been too many low-level publications & $\begin{array}{l}206 \\
(83.7)\end{array}$ & $\begin{array}{l}10 \\
(62.5)\end{array}$ & $\begin{array}{l}91 \\
(86.7)\end{array}$ & $\begin{array}{l}105 \\
(84.0)\end{array}$ & 0.081 \\
\hline There have been publications that led to difficulties treating patients & $\begin{array}{l}190 \\
(77.2)\end{array}$ & $\begin{array}{l}12 \\
(75.0)\end{array}$ & $\begin{array}{l}92 \\
(87.6)\end{array}$ & $\begin{array}{l}86 \\
(68.8)\end{array}$ & 0.019 \\
\hline \multicolumn{6}{|l|}{ Have the following SEMICYUC documents been useful? } \\
\hline Contingency plan for the intensive care services for the COVID-19 pandemic (11) & $\begin{array}{l}183 \\
(74.4)\end{array}$ & $\begin{array}{l}15 \\
(93.8)\end{array}$ & $\begin{array}{l}77 \\
(73.3)\end{array}$ & $\begin{array}{l}91 \\
(72.8)\end{array}$ & 0.495 \\
\hline De-escalation plan for Intensive Care Units (40) & $\begin{array}{l}155 \\
(63.0)\end{array}$ & $\begin{array}{l}12 \\
(75.0)\end{array}$ & $\begin{array}{l}62 \\
(59.0)\end{array}$ & $\begin{array}{l}81 \\
(64.8)\end{array}$ & 0.783 \\
\hline $\begin{array}{l}\text { Recommendations of the Working Groups from the Spanish Society of Intensive and Critical Care } \\
\text { Medicine and Coronary Units (SEMICYUC) for the management of adult critically ill patients in the } \\
\text { coronavirus disease (COVID-19)(13) }\end{array}$ & $\begin{array}{l}200 \\
(81.3)\end{array}$ & $\begin{array}{l}15 \\
(93.8)\end{array}$ & $\begin{array}{l}87 \\
(82.9)\end{array}$ & $\begin{array}{l}98 \\
(78.4)\end{array}$ & 0.545 \\
\hline $\begin{array}{l}\text { SEDAR-SEMICYUC consensus on the management of haemostasis disorders in severe COVID-19 } \\
\text { patients (19) }\end{array}$ & $\begin{array}{l}158 \\
(64.2)\end{array}$ & $\begin{array}{l}15 \\
(93.8)\end{array}$ & $\begin{array}{l}61 \\
(58.1)\end{array}$ & $\begin{array}{l}82 \\
(65.6)\end{array}$ & 0.144 \\
\hline $\begin{array}{l}\text { Pharmacological treatment of COVID-19: Narrative review of the Working Group in Infectious Diseases } \\
\text { and Sepsis (GTEIS) and the Working Groups in Transfusions and Blood Products (GTTH) (18) }\end{array}$ & $\begin{array}{l}170 \\
(69.1)\end{array}$ & $\begin{array}{l}13 \\
(81.3)\end{array}$ & $\begin{array}{l}68 \\
(64.8)\end{array}$ & $\begin{array}{l}89 \\
(71.2)\end{array}$ & 0.747 \\
\hline $\begin{array}{l}\text { Recommendations on cardiopulmonary resuscitation in patients with suspected or confirmed SARS- } \\
\text { CoV-2 infection (COVID-19). Executive summary (17) }\end{array}$ & $\begin{array}{l}171 \\
(69.5)\end{array}$ & $\begin{array}{l}14 \\
(87.5)\end{array}$ & $\begin{array}{l}68 \\
(64.8)\end{array}$ & $\begin{array}{l}89 \\
(71.2)\end{array}$ & 0.496 \\
\hline $\begin{array}{l}\text { Ultrasound in the management of the critically ill patient with SARS-CoV-2 infection (COVID-19): } \\
\text { narrative review (16) }\end{array}$ & $\begin{array}{l}143 \\
(58.1)\end{array}$ & $\begin{array}{l}11 \\
(68.8)\end{array}$ & $\begin{array}{l}51 \\
(48.6)\end{array}$ & $\begin{array}{l}81 \\
(64.8)\end{array}$ & 0.130 \\
\hline $\begin{array}{l}\text { Consensus document of the Spanish Society of Intensive and Critical Care Medicine and Coronary Units } \\
\text { (SEMICYUC), the Spanish Society of Otorhinolaryngology and Head and Neck Surgery (SEORL-CCC) and } \\
\text { the Spanish Society of Anesthesiology and Resuscitation (SEDAR) on tracheotomy in patients with } \\
\text { COVID-19 infection (14) }\end{array}$ & $\begin{array}{l}122 \\
(49.6)\end{array}$ & $\begin{array}{l}13 \\
(81.3)\end{array}$ & $\begin{array}{l}46 \\
(43.8)\end{array}$ & $\begin{array}{l}63 \\
(50.4)\end{array}$ & 0.189 \\
\hline $\begin{array}{l}\text { Ethical recommendations for a difficult decision-making in intensive care units due to the exceptional } \\
\text { situation of crisis by the COVID-19 pandemia: A rapid review \& consensus of experts (15) }\end{array}$ & $\begin{array}{l}174 \\
(70.7)\end{array}$ & $\begin{array}{l}14 \\
(87.5)\end{array}$ & $\begin{array}{l}74 \\
(70.5)\end{array}$ & $\begin{array}{l}86 \\
(68.8)\end{array}$ & 0.792 \\
\hline $\begin{array}{l}\text { Clinical consensus recommendations regarding non-invasive respiratory support in the adult patient } \\
\text { with acute respiratory failure secondary to SARS-CoV-2 infection (12) }\end{array}$ & $\begin{array}{l}174 \\
(70.7)\end{array}$ & $\begin{array}{l}15 \\
(93.8)\end{array}$ & $\begin{array}{l}72 \\
(68.6)\end{array}$ & $\begin{array}{l}87 \\
(69.6)\end{array}$ & 0.414 \\
\hline
\end{tabular}

Results are expressed as $\mathrm{n}(\%)$

\section{Supplementary Files}

This is a list of supplementary files associated with this preprint. Click to download.

- AdditionalFile1.docx 